\title{
Short communication: Effects of different whey concentrations on physicochemical characteristics and viable counts of starter bacteria in dairy beverage supplemented with probiotics
}

\author{
W. F. Castro, ${ }^{* 1}$ A. G. Cruz, ${ }^{*}$ D. Rodrigues, ${ }^{*}$ G. Ghiselli, ${ }^{*}$ C. A. F. Oliveira,† J. A. F. Faria, ${ }^{*}$ and H. T. Godoy* \\ *Universidade Estadual de Campinas (UNICAMP), Faculdade de Engenharia de Alimentos (FEA), Cidade Universitária Zeferino Vaz, \\ 13083-862, Campinas, São Paulo, Brazil \\ †Universidade de São Paulo (USP), Faculdade de Zootecnia e Engenharia de Alimentos Campus da USP (FZEA), Pirassununga, \\ 13635-900, São Paulo, Brazil
}

\begin{abstract}
Fermented dairy beverages supplemented with the probiotics Lactobacillus acidophilus and Bifidobacterium lactis containing different concentrations of whey in their formulas $(0,20,35,50,65$, and $80 \%$, vol/vol) were processed and checked for $\mathrm{pH}$; proteolysis; levels of glucose, lactose, ethanol, acetic acid, lactic acid, diacetyl, and acetaldehyde; and lactic bacteria and probiotic counts. The results allowed the effect of whey concentration on the dairy beverages to be observed for each of the different parameters analyzed. The degree to which the whey concentration was useful for the microbial cultures, particularly probiotic cultures, appeared to have a limit. In general, dairy beverages processed with different levels of whey in their formulation exhibited good potential as a food matrix for supplementation with probiotic bacteria, with production of characteristic compounds of fermented milk products, such as volatiles and organic acids.
\end{abstract}

Key words: dairy beverage, metabolite, probiotic, whey

\section{Short Communication}

The growth of the market for fermented milks constitutes an opportunity for the development of wheybased beverages of high nutritional and sensory value, along with a considerable reduction in processing costs (Gallardo-Escamilla et al., 2005), to the extent that the levels of lactose and other nutrients essential for microbial growth naturally present in whey provide better conditions for growth and viability of the microorganisms (Panesar et al., 2007; Magalhães et al., 2011).

In addition to the capacity to generate antihypertension peptides (Madureira et al., 2010), whey alone

Received March 27, 2012.

Accepted September 1, 2012.

${ }^{1}$ Corresponding author: wellfreitas@gmail.com intrinsically imparts a series of human health benefits (Madureira et al., 2007). It has been used as a raw material for developing and manufacturing edible antimicrobial films (Ramos et al., 2012) and microcapsules (Rodrigues et al., 2011). Recently, the consumption of whey has been suggested as a possible reason for the longevity of the Portuguese people (Tavares and Malcata, 2012). With respect to processed food products, dairy products, including cheeses (Madureira et al., 2011) and dairy beverages (Dragone et al., 2009; Pescuma et al., 2010) containing whey in their formulation, have shown potential for supplementation with probiotic bacteria.

However, the effect of different levels of added whey on the survival and metabolism of probiotic bacteria has not been evaluated so far. Within this context, the objective of this study was to assess the survival and metabolism of probiotic bacteria in dairy beverages formulated with different levels of whey.

The probiotic beverages were formulated with pasteurized milk $[\mathrm{pH} 6.63,3 \%$ (wt/vol) fat content] from the São José Dairy Farm located in Santo Antônio de Posse, São Paulo, Brazil, and whey [pH 6.26, 1.24\% (wt/ vol) protein content] obtained during the manufacture of Minas Frescal cheese by the enzyme coagulation process, with the whey drained off before salting. In total, 6 different beverages were manufactured, containing 0 , $20,35,50,65$, and $80 \%$ whey (vol/vol), respectively, with the remaining percentage volume being completed with milk, taking into account the volume of inoculum. Sugar (Caravela, Ariranha, São Paulo, Brazil) was added at a concentration of $10 \%$ (wt/vol) of the probiotic beverage, and the resulting mixtures were subjected to a heat treatment of $83^{\circ} \mathrm{C}$ for $15 \mathrm{~min}$. Upon conclusion of the heat treatment, the mixtures were cooled to $46^{\circ} \mathrm{C}$ and the following were added: (1) $1 \%$ (wt/vol) of a ready-to-use fruit preparation (Industrial Duas Rodas, Jaraguá do Sul, Santa Catarina, Brazil) consisting of strawberry pulp and colorant to prepare the beverages; (2) $1 \%$ starter culture inoculum (vol/vol); and 
(3) $2 \%$ ( vol/vol) of the amount of the probiotic culture, proportional to the product volume. The inocula were prepared from reconstituted skim milk powder (Molico, São Paulo, Brazil; $11 \%$ wt/vol), with addition of direct vat set (DVS) cultures of Streptococcus thermophilus (TA-40; DuPont, Copenhagen, Denmark) and Lactobacillus delbrueckii ssp. bulgaricus (LB-340; DuPont), plus a probiotic culture consisting of a blend of Lactobacillus acidophilus (La-14; DuPont) and Bifidobacterium lactis (Bl-07; DuPont). The inocula media were prepared using DVS cultures at concentrations of $0.1 \mathrm{~g}$ of probiotic and $0.05 \mathrm{~g}$ of starter culture (each per liter).

The resulting samples were then kept at $45^{\circ} \mathrm{C}$ during fermentation. Once $\mathrm{pH} 4.7 \pm 0.01$ was reached, fermentation was interrupted by cooling to $8^{\circ} \mathrm{C}$, and the test samples were stored under refrigeration $\left(5 \pm 1^{\circ} \mathrm{C}\right)$ in 300-mL plastic polyethylene terephthalate bottles.

The probiotic dairy beverages were submitted to the following analyses at $7 \mathrm{~d}$ of refrigerated storage, using previously published methodologies: $\mathrm{pH}$ (Marshall, 1993); proteolytic activity using the $o$-phthaldialdehyde (OPA) method (Church et al., 1983); glucose, lactose, lactic acid, and acetic acid contents (Donkor et al., 2005); and diacetyl and acetaldehyde (Condurso et al., 2008). The biochemical analyses were carried out in triplicate. For the microbiological analyses, the following analytical methodologies were used: Strep. thermophilus (M17 agar; Difco, Detroit, MI), pour plate, incubated aerobically for $2 \mathrm{~d}$ at $37^{\circ} \mathrm{C}$; Lactobacillus bulgaricus counts [de Man, Rogosa, Sharpe (MRS) agar; Oxoid, Basingstoke, UK], $\mathrm{pH} 5.2$, pour plate, incubated anaerobically for $3 \mathrm{~d}$ at $45^{\circ} \mathrm{C}$ (Cruz et al., 2012b); Bifidobacterium lactis count (MRS agar; Oxoid), supplemented with $0.6 \% \mathrm{LiCl}$ (wt/wt; Synth, Diadema, Brazil); and 0.9\% sodium propionate (wt/wt; Sigma-Aldrich, St. Louis, $\mathrm{MO}$ ), pour plate, incubated anaerobically (GasPak, Oxoid) for $3 \mathrm{~d}$ at $37^{\circ} \mathrm{C}$ (Zacarchenco and MassaguerRoig, 2004); and Lactobacillus acidophilus count (MRS agar; Oxoid), supplemented with $0.15 \%$ bile salt (wt/ wt; Oxoid), pour plate, incubated aerobically for $3 \mathrm{~d}$ at $37^{\circ} \mathrm{C}$ (Mortazavian et al., 2007). All the culture media were tested previously, aiming to guarantee their selectivity regarding the microorganisms. The microbiological analyses were carried out in duplicate.

The experiments were repeated 2 times. The data were submitted to one-way ANOVA, with the probiotic whey beverage considered the source of variation. When needed, the calculations were followed by Tukey's test $(P<0.05)$. All analyses were carried out using Assistat software (version 7.6 \&, 2011; Paraíba, Brazil).

Table 1 depicts the results of the biochemical and microbiological analyses of the probiotic dairy beverages produced with different levels of whey. In general, the effect of the increase in whey concentration on the dairy beverage could be observed in the various parameters assessed $(P<0.05)$. However, the extent to which the whey concentration could be used (i.e., further converted) by the microbial cultures beyond a certain point did seem to have a limit, particularly for the probiotic cultures. On the one hand, this should be seen as a potential advantage because it demonstrates the possibility of developing products with high whey concentrations and high microorganism counts that are beneficial to human health. On the other hand, it makes it absolutely necessary to conduct consumer tests of the product to improve the beverage formulation so as to yield a final product that is both functional and acceptable to consumers.

Proteolysis in fermented milk occurs from the metabolism of proteins to obtain essential AA during the growth of microorganisms and contributes to the development of their sensory properties in the fermented milks, such as aroma, flavor, and texture (Savijoki et al., 2006). Proteolysis increased as the concentration of whey increased to $65 \%$ of whey (vol/vol; $P<0.05$ ), suggesting a limited use of the cheese whey nutrients by the lactic and probiotic bacteria.

The Strep. thermophilus and L. bulgaricus counts ( $P$ $>0.05)$ were higher than $8 \log \mathrm{cfu} / \mathrm{mL}$ even after $7 \mathrm{~d}$ of refrigerated storage, in agreement with other recent

Table 1. Microbiological viable counts and physicochemical analyses of probiotic dairy beverages after $7 \mathrm{~d}$ of storage at $5^{\circ} \mathrm{C}^{1}$

\begin{tabular}{|c|c|c|c|c|c|c|c|c|c|c|c|c|c|}
\hline $\begin{array}{l}\text { Whey } \\
(\%)\end{array}$ & $\mathrm{pH}$ & Proteolysis & ST & $\mathrm{LB}$ & LA & BL & Lactose & Glucose & $\begin{array}{c}\text { Acetic } \\
\text { acid }\end{array}$ & $\begin{array}{c}\text { Lactic } \\
\text { acid }\end{array}$ & Diacetyl & Acetaldehyde & Ethanol \\
\hline 0 & 4.09 & $0.39^{\mathrm{bc}}$ & $8.77^{\mathrm{a}}$ & $8.31^{\mathrm{a}}$ & $8.83^{\mathrm{a}}$ & $4.24^{\mathrm{a}}$ & $25.70^{\mathrm{b}}$ & $25.00^{\mathrm{a}}$ & $0.45^{\mathrm{a}}$ & $8.89^{\mathrm{a}}$ & $31.05^{\mathrm{d}}$ & $3.83^{\mathrm{e}}$ & $40.41^{\mathrm{d}}$ \\
\hline 20 & 4.07 & $0.29^{\mathrm{c}}$ & $8.66^{\mathrm{a}}$ & $8.28^{\mathrm{a}}$ & $8.69^{\mathrm{a}}$ & $4.15^{\mathrm{a}}$ & $26.30^{\mathrm{b}}$ & $26.40^{\mathrm{a}}$ & $0.59^{\mathrm{a}}$ & $8.74^{\mathrm{a}}$ & $63.13^{\mathrm{c}}$ & $14.53^{\text {cd }}$ & $73.67^{\mathrm{a}}$ \\
\hline 50 & 4.08 & $0.47^{\mathrm{b}}$ & $8.63^{\mathrm{a}}$ & $8.05^{\mathrm{a}}$ & $8.77^{\mathrm{a}}$ & $3.00^{\mathrm{b}}$ & $35.20^{\mathrm{a}}$ & $28.90^{\mathrm{a}}$ & $0.45^{\mathrm{a}}$ & $8.06^{\mathrm{ab}}$ & $109.18^{\mathrm{b}}$ & $26.22^{\mathrm{b}}$ & $52.52^{\text {bcd }}$ \\
\hline 65 & 4.11 & $0.64^{\mathrm{a}}$ & $8.82^{\mathrm{a}}$ & $8.02^{\mathrm{a}}$ & $8.78^{\mathrm{a}}$ & $4.00^{\mathrm{a}}$ & $36.50^{\mathrm{a}}$ & $32.50^{\mathrm{a}}$ & $0.54^{\mathrm{a}}$ & $7.14^{\mathrm{ab}}$ & $37.60^{\mathrm{d}}$ & $21.14^{\mathrm{bc}}$ & $47.02^{\mathrm{cd}}$ \\
\hline 80 & 4.07 & $0.48^{\mathrm{b}}$ & $8.73^{\mathrm{a}}$ & $8.08^{\mathrm{a}}$ & $8.69^{\mathrm{a}}$ & $4.54^{\mathrm{a}}$ & $35.50^{\mathrm{a}}$ & $30.30^{\mathrm{a}}$ & $0.50^{\mathrm{a}}$ & $6.08^{\mathrm{b}}$ & $256.00^{\mathrm{a}}$ & $43.32^{\mathrm{a}}$ & $62.80^{\text {abc }}$ \\
\hline
\end{tabular}

${ }^{\mathrm{a} e}$ Different superscript letters within the same column indicate a statistical difference among treatments $(P<0.05)$.

${ }^{1}$ Proteolysis is expressed in absorbance at $340 \mathrm{~nm}$. Streptococcus thermophilus (ST), Lactobacillus bulgaricus (LB), Lactobacillus acidophilus (LA), and Bifidobacterium lactis (BL) are expressed in log colony-forming units per milliliter. Lactose, glucose, acetic acid, and lactic acid are expressed in milligrams per milliliter. Ethanol, diacetyl, and acetaldehyde are expressed in micrograms per milliliter. 
studies on probiotic yogurts and beverages (Cruz et al., 2010; Marafon et al., 2011).

With regard to the probiotic cultures, the $L$. acidophilus and B. lactis counts ranged from 8.69 to 8.83 and from 3.00 to $4.54 \log \mathrm{cfu} / \mathrm{mL}$, respectively, confirming the ability of the whey beverage to serve as a food matrix or as a food system that could be supplemented with counts of probiotic bacteria capable of delivering human health benefits, mainly toward the L. acidophilus counts. This finding corroborated the results of previously published studies (Oliveira et al., 2002; Madureira et al., 2007; Zoellner et al., 2009). The low viability of $B$. lactis can be attributed to the presence of or increase in oxygen dissolved during the preparation of the inoculate or processing of the beverages during the cooling step after fermentation because of agitation of the product to increase heat exchange and minimize postacidification (Talwalkar and Kailasapathy, 2004). Similar results were observed in Arabian probiotic fermented milk, with bifidobacteria counts showing approximately $4 \log \mathrm{cfu} / \mathrm{mL}$ after 3 wk of refrigerated storage (Al-Otaibi, 2009), and in other Bifidobacterium strains, such as Bifidobacterium longum in Cheddar cheese (Fortin et al., 2010).

However, even considering the difference in the Bifidobacterium lactis count $(P<0.05)$, no significant difference was found between the acetic acid levels among the beverages $(0.45$ to $0.59 \mu \mathrm{g} / \mathrm{g} ; P>0.05)$. This finding can be an advantage from the industrial standpoint because high levels of whey reduce production costs and do not contribute to an increase in the synthesis of acetic acid, which would cause decreased sensory acceptance by the consumers (Cruz et al., 2012a). A difference in the lactic acid content was observed, with $80 \%$ ( $\mathrm{vol} / \mathrm{vol}$ ) cheese whey exhibiting lower levels of this compound as compared with 0,20 , and $35 \%(P<$ $0.05)$, suggesting that even if the peptides contained in the whey had a greater availability, a limit existed to which it could be metabolized by the probiotic cultures.

The similarity among the glucose levels in all fermented probiotic beverages investigated in this study (25 to $32.5 \mu \mathrm{g} / \mathrm{g} ; P>0.05$ ) was justified because this parameter resulted directly from the consumption of lactose by the lactic cultures. Indeed, even with the increased amounts of whey contained in the beverage formulation, as reflected by the amount of lactose present, the results suggest that the microbial metabolism responsible for the hydrolysis of lactose into galactose and glucose did not occur equally and to the same degree in all formulations. Again, these findings suggest a maximum hydrolyzing capacity of the enzymes of the lactic cultures responsible for this transformation, which again emphasizes our previous comments.
With regard to the compounds responsible for the aroma of the final product, an overall increase in the concentrations of diacetyl and acetaldehyde was observed, proportional to the amount of whey in the beverage formulation $(P<0.05)$. However, irregular behavior was observed, with a decline in the values in $65 \%(\mathrm{vol} / \mathrm{vol})$ whey but a subsequent increase in $80 \%$ (vol/vol) whey, respectively. A possible explanation is the different qualitative and quantitative profiles of peptides and AA present because of fermentation of the whey dairy beverage formulation. At $80 \%$ (vol/ vol) whey, these precursors can be more easily used by the lactic cultures, whereas at $65 \%$ (vol/vol) whey, this result cannot occur. Further studies should clarify this unexpected tendency. It is important to report that the increased metabolic activity did not result in greater viability of the lactic bacteria. A similar result was observed with B. longum in Cheddar cheese (Scheller and O'Sullivan, 2011) and in yogurt with added glucose oxidase (Cruz et al., 2012c). However, our findings can be considered positive in the sense that these compounds are ultimately responsible for the aroma of fermented products (Cheng, 2010) because they are produced by the lactic cultures Strep. thermophilus and L. bulgaricus (Pinto et al., 2009).

Regarding the ethanol level, an additional factor that should be mentioned is the presence of the enzyme alcohol dehydrogenase, which metabolizes ethanol into acetaldehyde. This enzyme has been detected in probiotic bacteria, such as L. acidophilus (Marshall and Cole, 1983), and can explain the mild flavor of probiotic yogurts because acetaldehyde has a lower threshold compared with ethanol.

Recently, Castro et al. (2013), using different sensory methodologies, such as survival analysis, minimal significant difference, and mean global acceptance, reported that 49 and $65 \%$ (vol/vol) whey concentration values were the most adequate in the formulation of dairy beverages, taking consumer opinion into consideration. Future studies covering descriptive tests using trained assessors are necessary to establish the sensory profiling of the fermented dairy beverages, in such a way as to successfully develop a functional dairy product with good potential for marketing. Further studies should investigate the entire refrigerated storage period of whey beverages to obtain more conclusive results.

The results of this study suggest that fermented dairy beverages processed with increasing levels of whey in their formulation are adequate as food matrices for supplementation with probiotic bacteria, irrespective of the whey concentration present in the formulation. Overall, adequate production of organic acids and appropriate levels of aroma compounds were observed 
in the formulations evaluated. Nonetheless, high concentrations of whey did not result in higher counts of probiotic bacteria, suggesting that a natural limit exists in the degree to which the whey constituents can be metabolized by these microorganisms.

\section{ACKNOWLEDGMENTS}

The authors are grateful to CAPES (Coordenação de Aperfeiçoamento de Pessoal de Nível Superior), FAEPEX/UNICAMP (Fundo de Apoio ao Ensino, à Pesquisa e Extensão), and FAPESP (Fundação de Amparo à Pesquisa do Estado de São Paulo) for a doctoral scholarship and financing of the research, to Duas Rodas (Jaraguá do Sul, SBrazil) and Dölher (Limeira, Brazil) for providing and preparing the fruits, and to DuPont- Danisco (Copenhagen, Denmark) for the microbial cultures used.

\section{REFERENCES}

Al-Otaibi, M. M. 2009. Evaluation of some probiotic fermented milk products from Al-Ahsa markets, Saudi Arabia. Am. J. Food Technol. 4:1-8.

Castro, W. F., A. G. Cruz, M. S. Bisinotto, L. M. R. Guerreiro, J. A. F. Faria, H. M. A. Bolini, R. L. Cunha, and R. Deliza. 2013. Development of probiotic dairy beverages: Rheological properties and application of mathematical models in sensory evaluation. J. Dairy Sci. 96:16-25.

Cheng, H. 2010. Volatile flavor compounds in yogurt: A review. Crit. Rev. Food Sci. Nutr. 50:938-950.

Church, F. C., H. E. Swaisgood, D. H. Porter, and G. L. Catignani. 1983. Spectrophotometric assay using o-phthaldialdehyde for determination of proteolysis in milk and isolated milk proteins. J. Dairy Sci. 66:1219-1227.

Condurso, C., A. Verzera, V. Romeo, M. Ziino, and F. Conte. 2008. Solid-phase microextraction and gas chromatography-mass spectrometry analysis of dairy product volatiles for the determination of shelf-life. Int. Dairy J. 18:819-825.

Cruz, A. G., R. S. Cadena, J. A. F. Faria, H. M. A. Bolini, C. Dantas, M. M. C. Ferreira, and R. Deliza. 2012a. PARAFAC: Adjustment for modeling consumer study covering probiotic and conventional yogurt. Food Res. Int. 45:211-215.

Cruz, A. G., W. F. Castro, J. A. F. Faria, S. Bogusz Jr., D. Granato, R. M. S. Celeghini, J. Lima-Pallone, and H. T. Godoy. 2012b. Glucose oxidase: A potential option to decrease the oxidative stress in stirred probiotic yogurt. Lebenson. Wiss. Technol. 47:512-515.

Cruz, A. G., W. F. Castro, J. A. F. Faria, P. C. B. Lollo, J. AmayaFarfán, M. Q. Freitas, D. Rodrigues, C. A. F. Oliveira, and H. T. Godoy. 2012c. Probiotic yogurts manufactured with increased glucose oxidase levels: Postacidification, proteolytic patterns, survival of probiotic microorganisms, and production of organic acid and aroma compounds. J. Dairy Sci. 95:2261-2269.

Cruz, A. G., J. A. F. Faria, E. H. M. Walter, R. R. Andrade, R. N. Cavalcanti, C. A. F. Oliveira, and D. Granato. 2010. Optimization of the processing of probiotic yoghurt added with glucose oxidase using the response surface methodology. J. Dairy Sci. 93:1058-1069.

Donkor, O. N., A. Henriksson, T. Vasiljevic, and N. P. Shah. 2005. Probiotic strains as starter cultures improve angiotensin-converting enzyme inhibitory activity in soy yogurt. J. Food Sci. 70:375-381.

Dragone, G., S. I. Mussatto, J. M. Oliveira, and J. A. Teixeira. 2009 Characterization of volatile compounds in an alcoholic beverage produced by whey fermentation. Food Chem. 112:929-935.
Fortin, M.-H., C. P. Champagne, D. St-Gelais, M. Britten, M. P. Fustier, and M. Lacroix. 2010. Effect of time of inoculation, starter addition, oxygen level and salting on the viability of probiotic cultures during Cheddar cheese production. Int. Dairy J. 21:75-82.

Gallardo-Escamilla, F. J., A. L. Kelly, and C. M. Delahunty. 2005. Influence of starter culture in flavor and headspace volatile profiles of fermented whey and whey produced from fermented milk. J. Dairy Sci. 88:3745-3753.

Madureira, A. R., M. Amorim, A. M. Gomes, M. E. Pintado, and F. X. Malcata. 2011. Protective effect of whey cheese matrix on probiotic strains exposed to simulated gastrointestinal conditions. Food Res. Int. 44:465-470.

Madureira, A. R., C. I. Pereira, A. M. P. Gomes, M. E. Pintado, and F. X. Malcata. 2007. Bovine whey proteins - Overview on their main biological properties. Food Res. Int. 40:1197-1211.

Madureira, A. R., T. Tavares, A. M. P. Gomes, M. E. Pintado, and F. X. Malcata. 2010. Invited review: Physiological properties of bioactive peptides obtained from whey proteins. J. Dairy Sci. 93:437-455.

Magalhães, K. T., G. Dragone, G. V. M. Pereira, J. M. Oliveira, L. Domingues, J. A. Teixeira, J. B. Almeida e Silva, and R. F. Schwan. 2011. Comparative study of the biochemical changes and volatile compound formations during the production of novel whey-based kefir beverages and traditional milk kefir. Food Chem. 126:249-253.

Marafon, A. P., A. Surimi, M. R. Alcantara, A. Y. Tamime, and M. N. Oliveira. 2011. Optimization of the rheological properties of probiotic yoghurts supplemented with milk proteins. Lebenson. Wiss. Technol. 44:511-519.

Marshall, R. T. 1993. Standard Methods for the Examination of Dairy Products. Am. Public Health Assoc., Washington, DC.

Marshall, V. M., and W. M. Cole. 1983. Threonine and alcohol dehydrogenase activities in Lactobacillus bulgaricus and Lactobacillus acidophilus and their contribution to flavour production in fermented milks. J. Dairy Res. 50:375-379.

Mortazavian, A. M., E. M. Ehsani, S. M. Mousavi, K. Rezaei, S. Sorrabvandi, and J. A. Reinheimer. 2007. Effect of refrigerated storage temperature on the viability of probiotic microorganisms in yogurt. Int. J. Dairy Technol. 60:123-127.

Oliveira, M. N., I. Sodini, F. Remeuf, J. P. Tissier, and G. Corrieu. 2002. Manufacture of fermented lactic beverages containing probiotic cultures. J. Food Sci. 67:2336-2341.

Panesar, P. S., J. F. Kennedy, D. N. Gandhi, and K. Bunko. 2007. Bioutilisation of whey for lactic acid production. Food Chem. 105:1-14.

Pescuma, M., E. M. Hérbert, F. Mozzi, and G. F. de Valdez. 2010. Functional fermented whey-based beverage using lactic acid bacteria. Int. J. Food Microbiol. 141:73-81.

Pinto, S. M., M. G. Clemente, and L. R. Abreu. 2009. Behaviour of volatile compounds during the shelf-life of yogurt. Int. J. Dairy Technol. 62:215-222.

Ramos, Ó. L., S. I. Silva, J. C. Soares, J. C. Fernandes, M. F. Poças, M. E. Pintado, and F. X. Malcata. 2012. Features and performance of edible films obtained from whey protein isolate formulated with antimicrobial compounds. Food Res. Int. 45:351-361.

Rodrigues, D., S. Sousa, T. Rocha-Santos, J. P. Silva, J. M. Sousa Lobo, P. Costa, M. H. Amaral, M. M. Pintado, A. M. Gomes, F. X. Malcata, and A. C. Freitas. 2011. Influence of L-cysteine, oxygen and relative humidity upon survival throughout storage of probiotic bacteria in whey protein-based microcapsules. Int. Dairy J. 21:869-876.

Savijoki, K., H. Ingmer, and P. Varmeanen. 2006. Proteolytic systems of lactic acid bacteria. Appl. Microbiol. Biotechnol. 71:394-406.

Scheller, M., and D. J. O'Sullivan. 2011. Comparative analysis of an intestinal strain of Bifidobacterium longum and a strain of Bifidobacterium animalis subspecies lactis in Cheddar cheese. J. Dairy Sci. 94:1122-1131.

Talwalkar, A., and K. Kailasapathy. 2004. The role of oxygen in the viability of probiotic bacteria with reference to L. acidophilus and Bifidobacterium spp. Curr. Issues Intest. Microbiol. 5:1-8. 
Tavares, T. G., and F. X. Malcata. 2012. The Portuguese Paradox: Why do some inhabitants of Portugal appear to live so long when their diet is based on whey cheese? Food Chem. 131:727-729.

Zacarchenco, P. B., and S. Massaguer-Roig. 2004. Avaliação sensorial, microbiológica e de pós-acidificação durante a vida-de-prateleira de leites fermentados contendo Streptococcus thermophilus, Bifido- bacterium longum e Lactobacillus acidophilus. Ciên. Tecnol. Alim. 24:674-679.

Zoellner, S. S., A. G. Cruz, J. A. F. Faria, H. M. A. Bolini, M. R. L. Moura, L. M. J. Carvalho, and A. S. Sant'Ana. 2009. Whey beverage with acai pulp as a food carrier of probiotic bacteria. Aust. J. Dairy Technol. 64:165-169. 